\title{
44571 - CELL SAVER USE DURING CPB AND TRANSFUSION RATES AFTER CABG SURGERY
}

Disclosure: Grants/research support - Heart \& Stroke Foundation of Ontario

\author{
Nasr Hegazy, Toronto General Hospital, University Health Network, Toronto, ON, \\ Canada; \\ Ludwik Fedorko, Toronto General Hospital, University Health Network; \\ Michael Borger, Toronto General Hospital, University Health Network; \\ Robin Green, Toronto Rehabilitation Centre, University of Toronto; \\ J Carroll, Toronto General Hospital, University Health Network; \\ M Marcon; \\ BJ Anderson, Toronto General Hospital, University Health Network; \\ J Karski, Toronto General Hospital, University Health Network;
}

INTRODUCTION: Cardiotomy suction reservoir is used to return 'suctioned' blood from the wound, sternum and thorax back to the patient in order to minimize blood loss. However, blood collected in cardiotomy suction contains high levels of cellular debris and lipid microparticulates which can be efficiently removed by the cell saver. The objective of this study was to determine the effects of cell saver on hematological parameters and blood product transfusion rates in patients undergoing coronary revascularization surgery.

METHODS: After REB approval and informed consent, 226 patients were randomly allocated to either cell saver or cardiotomy suction (control) groups. The cell saver and cardiotomy suction were used during the same time periods, from when full heparinization (ACT > 400s) was established to after the initial dose of protamine was given. Anesthesia and surgical management was standardized. The sample size was calculated for the primary outcome of postoperative cognitive dysfunction. A sample size of 209 patients was required to see a $50 \%$ reduction in cognitive dysfunction (from $36 \%$ to $18 \%$ ) in patients receiving cell saver management strategy, with $\mathrm{a}=0.05$ and power $1-\mathrm{b}=0.8$.

RESULTS: There was no difference with respect to the baseline demographic data, preoperative variables, and surgical characteristics between the two groups. The amount of shed blood recycled via cardiotomy reservoir was $960 \pm 799 \mathrm{~mL}$, with a median of $800 \mathrm{~mL}$, and a range of $175-3840 \mathrm{~mL}$. The amount of red-cell concentrate transfused after processing via cell saver was $452 \pm 176 \mathrm{~mL}$, with a median of $401 \mathrm{~mL}$, and a range of $188-980 \mathrm{~mL}$. Patients in the cell saver group had higher hemoglobin levels during the first $24 \mathrm{~h}$ postoperative period. Patients in the control group had higher platelet count and lower INR and partial thromboplastin time values at intensive care unit admission. Postoperative 24-hour blood loss was $787 \pm 373 \mathrm{~mL}$ and $733 \pm 342 \mathrm{~mL}$ in the cell saver and control groups respectively, $\mathrm{p}=0.256$. A total of $28(25 \%)$ patients in the cell saver and 14(12\%) patients in the control groups received fresh frozen plasma (FFP) transfusion at any time during the perioperative period, $\mathrm{p}=0.018$. Furthermore, the probability of receiving FFP transfusion increased proportionately to the amount of transfused cell saver blood. 
Figure. The probability of the fresh frozen plasma (FFP) transfusion rates with respect to the amount of processed cell-saver transfusion.

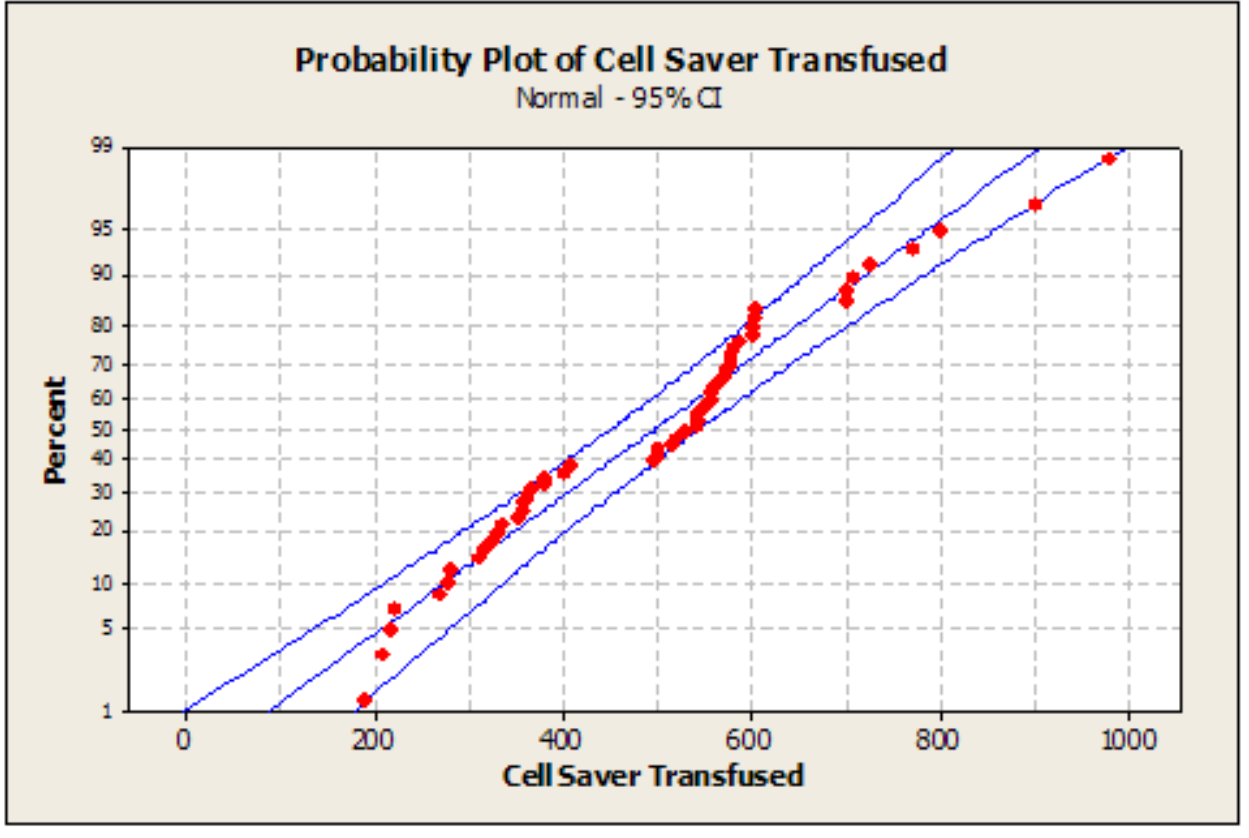

The packed red cell and platelet transfusion rates were similar between the two groups. DISCUSSION: The present study demonstrates that whilst the use of cell saver during cardiopulmonary bypass is associated with higher requirements from FFP transfusion. The probability of FFP transfusion increases proportionally to the amount cell saver blood transfused. 